\section{Low Tunnels Reduce Irrigation Water Needs and Increase Growth, Yield, and Water-use Efficiency in Brussels Sprouts Production}

\author{
Tej P. Acharya ${ }^{1}$, Gregory E. Welbaum, and Ramón A. Arancibia ${ }^{2}$ \\ School of Plant and Environmental Sciences, 330 Smyth Hall, Virginia Tech, \\ Blacksburg, VA 24061
}

Additional index words. rowcover, temperature, solar radiation, evapotranspiration

\begin{abstract}
Farmers use low tunnels (LTs) covered with spunbonded fabric to protect warm-season vegetable crops against cold temperatures and extend the growing season. Cool season vegetable crops may also benefit from LTs by enhancing vegetative growth and development. This study investigated the effect of the microenvironmental conditions under LTs on brussels sprouts growth and production as well as water requirements and use efficiency in comparison with those in open fields. Low tunnels increased minimum soil temperature in all trials. By contrast, LTs reduced evapotranspiration (ET) $54 \%$ to $68 \%$ by reducing solar radiation (SR) and blocking wind in spite of increased maximum air temperatures. Because of reduced ET, water needs and irrigation decreased by $\mathbf{2 4 \%}$ to $\mathbf{4 0 \%}$. Furthermore, LTs enhanced vegetative growth (plant leaf area, plant height, and plant dry weight). Sprouts per plant and yield under LTs increased by $29 \%$ and $46 \%$ in Spring 2017 , by $22 \%$ and $46 \%$ in Fall 2017 , and by $29 \%$ and $22 \%$ in Spring 2018. Considering the increased growth and productivity and reduced irrigation, LTs increased water-use efficiency (WUE) in relation to yield by $62 \%$ to $107 \%$ in comparison with open fields. Increased total yield and improved WUE illustrate that LTs may be a useful management tool in sustainable production systems in addition to their traditional role for season extension.
\end{abstract}

Protected production systems are used to modify the crop's microenvironment and extend the growing period early in the spring or late in the fall (Arancibia, 2018; Lamont, 2005). In addition, protected systems enhance vegetative growth and increase productivity, which may improve the sustainability of vegetable production operations. A wide variety of structures such as hotbeds, glass cloches, coldframe, low and high tunnels, and various types of greenhouses have been used as protected systems to extend the growing season (Lamont, 2005). Although farmers use protected cultivation systems for warm season vegetables, LTs can also benefit cool season vegetable crops by increasing

Received for publication 14 Sept. 2018. Accepted for publication 19 Dec. 2018.

This project is supported by the National Institute of Food and Agriculture, U.S. Department of Agriculture, under award number 2015-38640-23780, through the Southern Sustainable Agriculture Research and Education program under subaward number LS16-268.

Any opinions, findings, conclusions, or recommendations expressed in this publication are those of the author(s) and do not necessarily reflect the view of the U.S. Department of Agriculture or SARE. USDA is an equal opportunity employer and service provider. ${ }^{1}$ Graduate Research Assistant.

${ }^{2}$ Corresponding author. E-mail: raran@vt.edu.

This is an open access article distributed under the CC BY-NC-ND license (https://creativecommons. org/licenses/by-nc-nd/4.0/).

water (Arancibia, 2018). Low tunnels covered with spunbonded fabric increase vegetative growth and yield by increasing soil and air temperature (Arancibia, 2018; Arancibia and Motsenbocker, 2008; Gerber et al., 1988; Ibarra et al., 2001; Jolliffe and Gaye, 1995; Nair and Ngouajio, 2010). In addition, LTs are movable, allowing for crop rotation with cover crops in sustainable production systems.

Many vegetable species are shallow rooted and are sensitive to mild water stress (Feigin et al., 1982; Sammis, 1980). Therefore, irrigation is important in vegetable crops to maintain adequate soil moisture for continuous growth and development. However, more than $90 \%$ of the water used by plants is lost through transpiration (Morison et al., 2008). In most agricultural systems, poor WUE occurs when soil evaporation is high as compared with plant transpiration in the same field (Gallardo et al., 1996). Water lost through evaporation and transpiration is known as ET, which depends on environ- mental conditions and plant stage (size). Increased ET results in increased crop water needs. Factors influencing ET are SR, crop growth stage, daylength, air temperature, relative humidity $(\mathrm{RH})$, and wind speed (Allen et al., 1998; Jensen and Allen, 2016; Zotarelli et al., 2010). Therefore, fully grown plants demand larger amounts of water, especially in warm, sunny, and windy days (Abdrabbo et al., 2010). Under LT, however, rowcover reduces direct sunlight and blocks wind, which reduces ET even at higher temperatures (Arancibia, 2009, 2012). Therefore, reducing ET in crops grown under LTs may reduce irrigation requirements and improve WUE.

The use of LT can be beneficial to extend the harvest season of brussels sprouts (Brassica oleracea L. Group Gemmifera). Brussels sprout is a cool season, frost-tolerant vegetable crop from the family Brassicaceae. It is an important source of dietary fiber, vitamins $(\mathrm{A}, \mathrm{C}$, and $\mathrm{K})$, calcium $(\mathrm{Ca})$, iron $(\mathrm{Fe})$, manganese $(\mathrm{Mn})$, and antioxidants (U.S. Department of Agriculture, 2018). In 2017, the United States imported fresh and frozen brussels sprouts valued at $\$ 56$ million but exported only $\$ 16$ million of similar sprout products (U.S. Department of Agriculture, 2017). Therefore, the United States is underproducing brussels sprouts. The main brussels sprouts production season is fall, but spring production is also possible, and extending the harvest season by growing under LTs may help increase local production for direct sale markets.

The hypothesis for this study was that LTs create a more favorable environment in both spring and late summer-fall that would reduce ET and irrigation while increasing vegetative growth and yield. Therefore, the objectives were a) to determine the differences in microenvironmental conditions between LT and open field, and their association with irrigation requirement and b) to determine differences in vegetative growth, production, and WUE in brussels sprouts grown under LT and open field.

\section{Materials and Methods}

Brussels sprouts, cultivar Dimitri, were grown on a Bojac sandy loam soil in Spring 2017, Fall 2017, and Spring 2018 at the Eastern Shore Agricultural Research and Extension Center-Virginia Tech in Painter, Virginia (lat. 37.58466, long. -75.82114). All trials were set up in a spilt-plot design with four replications. The main effect (plots) consisted of two plastic mulches (white and black) and the secondary effect (subplot) consisted of treatments with LT and open field. The field had five $60-\mathrm{m}$-long rows (1.8 $\mathrm{m}$ center to center): two guard rows along the border and one additional guard row in the middle between the two record rows. Four 15-m-long blocks (replication) were separated along the field. Mulch color was assigned randomly to each record row (plots), which was divided into two 6-m-long subplots separated by a $1.5-\mathrm{m}$ alley. Treatments (LT and open field) were allocated randomly to each subplot. 
Brussels sprout seedlings were grown under greenhouse conditions in MarchApril $\left(20^{\circ} \mathrm{C}\right)$ and July $\left(32^{\circ} \mathrm{C}\right)$ for the spring and fall planting, respectively. Seedlings (45 weeks old, 9-11 cm tall) were hand-planted into double-row beds on 12 Apr. 2017, 10 Aug. 2017, and 25 Apr. 2018 (Table 1). Planting was on raised beds $(0.2 \mathrm{~m}$ tall and $0.8 \mathrm{~m}$ wide) $1.8 \mathrm{~m}$ apart (center to center) with the appropriate plastic mulch color ( $0.003 \mathrm{~cm}$ thick and $152.4 \mathrm{~cm}$ wide) (Hilex poly Co., North Vernon, IN). In-row planting distance was $0.6 \mathrm{~m}$ and rows in the same bed were $0.45 \mathrm{~m}$ apart. Drip irrigation was laid between rows under plastic (Aqua Trax, EI Cajon, CA). Emitters in the irrigation tape were $30 \mathrm{~cm}$ apart, and the flow rate was 1.89 $\mathrm{L} \cdot \mathrm{min}^{-1}$ per $30 \mathrm{~m}$ tape length. Tunnels were set up with polyvinyl chloride hoops $(3 \mathrm{~m}$ long) bent to form a $1.0-\mathrm{m}$ tall and $1.0-\mathrm{m}$ wide tunnel, which was covered with spunbonded rowcover (Dewitt, Sikeston, MO) of $33.8 \mathrm{~g} \cdot \mathrm{m}^{-2}$ in the two spring trials and 16.9 $\mathrm{g} \cdot \mathrm{m}^{-2}$ in the fall trial. Sand bags were used on the sides to hold the edges in place. Pre-plant fertilizer $(10 \mathrm{~N}-4.4 \mathrm{P}-8.3 \mathrm{~K})$ was incorporated into planting beds at $112.5 \mathrm{~kg} \cdot \mathrm{ha}^{-1}$ of $\mathrm{N}$ according to the Mid-Atlantic Commercial Vegetable Production Recommendations for brussels sprouts (Wyenandt, 2016) using a rotary tiller before laying polyethylene mulch in all trials. A one-time sidedressing at $14.5 \mathrm{~kg} \cdot \mathrm{ha}^{-1}$ of $\mathrm{N}$ was applied through the dripline to all treatments and trials. All other cultural practices followed the Mid-Atlantic Commercial Vegetable Production Recommendations (Wyenandt, 2016).

Environmental parameters and irrigation. Dataloggers (EM50R; Decagon Devices, Pullman, WA) were installed after transplanting in all trials to monitor microenvironmental conditions throughout the growing period. Sensors were connected directly to the dataloggers, and hourly data were transmitted via radio frequencies to a central storage station connected to a computer. Soil temperature and moisture were monitored in two replications in Spring 2017, three replications in Fall 2017, and four replications in Spring 2018. Air temperature and $\mathrm{RH}$ were monitored in two replications in both Spring 2017 and 2018 but only one in Fall 2017. Soil temperature and moisture sensors (5TM; Decagon Devices) were set at a depth of $15 \mathrm{~cm}$. Air temperature and RH sensors (VP3; Decagon Devices) were $30 \mathrm{~cm}$ aboveground (plant canopy level) in both treatments as it was necessary to monitor parameters inside the LT. Solar radiation sensor (Pyranometer; Apogee, North Logan, UT) was above the canopy also to fit inside the LT. Wind speed was monitored (Davis Cup Anemometer; Decagon Devices) in the open field, but because of the difficulties in maintaining the anemometer free for movement, wind under LT was considered undetectable based on previous work (Arancibia, 2009, 2012). Daily maximum and minimum air temperatures, daily total SR, daily maximum and minimum $\mathrm{RH}$, and daily average wind speed were used to determine ET using the Penman-Monteith Daily equation (Synder and Eching, 2007). Because brussels sprout is a medium-sized crop ( $>40 \mathrm{~cm}$ tall) at maturity, the ET equation for tall canopies was used. The program also takes into consideration the date and location (latitude and altitude). Environmental parameters (soil temperature, air temperature, RH, SR, wind speed, and ET) were monitored from the day of LT installation to the day before removal (Table 1).

Irrigation events based on soil moisture status and total irrigation water applied were determined in Spring 2017 and 2018 but not in Fall 2017. Irrigation events were initiated at $40 \%$ to $50 \%$ deficit of plant available water. The amount of water applied depended on the amount of water needed to bring soil moisture up to field capacity and the volume of the root zone. Based on Part 623 of the National Engineering Handbook (U.S. Department of Agriculture, 2013), soil moisture at field capacity in a sandy loam soil is $22 \%$ volumetric water content, and $50 \%$ plant available water deficit is at $16 \%$ volumetric water content. Therefore, the amount of water to apply was calculated by using the following formula:

$$
\text { Water volume }=(D \times W \times L) \times 6 \%,
$$

where $D$ is the depth of the root zone, $W$ is the width of the root zone, $L$ is the length of the row (subplot), and $6 \%$ is the volumetric water content to replenish. Then, irrigation time was calculated by dividing the water volume needed by the drip tape flow rate. In the initial stages, plants were irrigated for $43 \mathrm{~min}$. Thirty days after transplanting (DAT) and $60 \mathrm{DAT}$, the irrigation time was 2 and $3 \mathrm{~h}$, respectively.

Plant growth, yield, and WUE. Leaf area per plant, leaf dry weight, and specific leaf area were measured by harvesting one plant from each subplot 60 DAT in both spring trials and at harvest in the fall trial. Leaf area from each plant (all leaves) was measured using a leaf area meter (LI-3100; Li COR, Inc., Lincoln, Nebraska). Then, leaf samples were dried at $70{ }^{\circ} \mathrm{C}$ for at least $15 \mathrm{~d}$ and weighed to determine leaf dry weight. Leaf area was divided by leaf dry weight to determine specific leaf area.

Before harvest, brussels sprouts were decapitated (removal of the apex) on 20 June
2017 and 27 June 2018 in the spring trials and on 20 Oct. in the fall trial to promote the development of auxiliary buds (sprouts). Then at harvest, four plants were selected randomly from each subplot to determine plant height (stem length), plant dry weight, number of sprouts, and yield. Hence, 16 plants were collected from each treatment. Plant height was measured from the base of the plant to the top of the stem. Number of sprouts per plant and yield of brussels sprouts were determined by harvesting all mature axillary buds. Maturity and harvest time were determined visually when most of the sprouts in the plants were wider than $2.5 \mathrm{~cm}$ in diameter (U.S. Department of Agriculture, 2016), and in the spring trials, when the outer leaves of the sprouts started to open, losing firmness (warm conditions).

Water-use efficiency was determined in relation to growth and production parameters. Yield, number of sprouts, and plant dry weight were obtained at harvest from each subplot as described previously. Irrigation events and applied water were monitored throughout the trials as described previously. WUE was determined for growth and production by dividing the estimated number of sprouts, yield, and dry weight in each subplot (production area) by the total applied irrigation water to the same production area.

Statistical analysis. Data from all parameters were analyzed using Minitab 2018 software (Minitab ${ }^{\circledR}$ Statistical Software 2018, State College, PA). Analysis of variance was conducted to evaluate the significance of treatment effects. Mean of each parameter was compared by using Fisher's least significant difference at $P \leq 0.05$. Time series plots, trend lines, and bar graphs were plotted in Excel 2016 (Microsoft Corp., Redmond, WA).

\section{Results}

Environmental parameter and irrigation. There was no interaction between mulch and LT in all trials, except for minimum soil temperature in Spring 2017. In general, black mulch increased soil temperature (average across LT), except for maximum temperature in Spring 2017 and minimum temperature in Fall 2017 (Table 2). Maximum soil temperature increased by 1.6 and $1.0^{\circ} \mathrm{C}$ in Fall 2017 and Spring 2018, respectively (Table 2). Minimum soil temperature increased by $0.6{ }^{\circ} \mathrm{C}$ in Spring 2018. Black mulch also increased minimum soil temperature in Spring 2017 by 0.6 and $1.3{ }^{\circ} \mathrm{C}$ under LT and open field, respectively. Similarly, LT increased the minimum soil temperature in

Table 1. Schedule of planting, tunnel installation, tunnel removal, and harvest of brussels sprouts trials.

\begin{tabular}{|c|c|c|c|}
\hline & Spring 2017 & Fall 2017 & Spring 2018 \\
\hline Transplant & 12 Apr. & 10 Aug. & 25 Apr. \\
\hline LT installation & 12 Apr. (0 DAT) & 10 Aug. (0 DAT) & 9 May (14 DAT) \\
\hline Decapitation & 20 June (69 DAT) & 20 Oct. (71 DAT) & 27 June (63 DAT) \\
\hline LT removal & 20 June (69 DAT) & 19 Nov. (101 DAT) & 16 July (82 DAT) \\
\hline Harvest & 3 and 10 July (82 DAT and 89 DAT) & 19 Nov. (101 DAT) & 29 July (95 DAT) \\
\hline
\end{tabular}

$\mathrm{LT}=$ low tunnel; DAT $=$ days after transplanting. 
all trials, but there were no differences in maximum soil temperature. Minimum soil temperature under LT increased by 0.7 and $0.4{ }^{\circ} \mathrm{C}$ in Fall 2017 and Spring 2018, respectively. In Spring 2017, LT also increased minimum soil temperature by 0.5 and $1.2{ }^{\circ} \mathrm{C}$ under black and white mulch, respectively.

Low tunnels also increased maximum air temperature throughout the growing period in comparison with open field in all trials, but minimum air temperature was the same (Table 3). Maximum air temperature under tunnels increased by 4.2 and $8.6^{\circ} \mathrm{C}$ in Spring 2017 and 2018, respectively, in comparison with open field (Table 3). Although air temperature in Fall 2018 was monitored in one replication only, the difference in average maximum temperature between LT and open field is similar to that in the spring trials.

Daily SR, RH, and wind speed under LT and open field were monitored to estimate ET. Based on the combined data from the three trials, average daily SR under LT and open field was 12.0 and $17.5 \mathrm{MJ} \cdot \mathrm{d}^{-1}$, respectively, a $31 \%$ reduction by the rowcover (data not presented). Average maximum RH under LT from the three trials was $92 \%, 4 \%$ greater than that in open field. Daily average minimum RH under LT and open field from the three trials was $57 \%$ and $56 \%$, respectively. Similarly, average wind speed in open field from the three trials was $0.58 \mathrm{~m} \cdot \mathrm{s}^{-1}$ in comparison with undetectable wind inside the tunnel (Arancibia, 2009, 2012).

Daily air temperature, RH, SR, and wind speed were used to determine daily ET (tall canopy) under LT and open field. Low tunnel decreased daily ET in comparison with open field conditions throughout the treatment period in all trials (Fig. 1). In Spring 2017, average daily ET under LT and in open field were 1.64 and $4.06 \mathrm{~mm}$, respectively $(60 \%$ ET reduction). In Fall 2017, ET under LT and in open field were 1.10 and $3.47 \mathrm{~mm}$, respectively (68\% ET reduction). Similarly, in Spring 2018, average daily ET under LT and in the open field were 2.35 and $5.08 \mathrm{~mm}$, respectively (54\% ET reduction). Overall, average ET reduction under LT in all three trials was $60 \%$.

Low tunnels reduced irrigation needs of brussels sprouts in both spring trials. There were no differences in irrigation events between black and white mulch, and no statistical interaction between LT and mulch, so data were pooled together. Figure 2, however, shows the progression of soil moisture (volumetric water content) and irrigation events throughout the growing period for one replication under LT and in open field. In the first month of both trials, soil moisture stayed above $50 \%$ deficit likely because of the sensor's location outside/beneath the root zone (small plants) and heavy rainfall, so irrigation was mainly applied for plant establishment and fertilization. Low tunnel reduced the rate of soil moisture loss between irrigation events and maintained a greater soil water content, especially in the second half of the growing period (large plants). Low tunnel reduced the number of irrigation events necessary to replenish soil moisture from 15 in open field to 7 under LT in Spring 2017 (53\% reduction) and from 11.4 in open field to 6.8 under LT in Spring 2018 (40\% reduction) (Fig. 3). Consequently, LT reduced the total amount of irrigation water applied by $40 \%$ (from 106 to $64 \mathrm{~L} \cdot \mathrm{m}^{-1}$ ) and $24 \%$ (from 157 to $120 \mathrm{~L} \cdot \mathrm{m}^{-1}$ ) in Spring 2017 and Spring 2018, respectively. In addition, a linear relationship was found between cumulative irrigation (combined both years) and cumulative ET under LT $(r=0.89$,
$P$ value $<0.0001)$ and in open field $(r=0.88$, $P$ value $<0.0001$ ) (Fig. 4).

Growth, production, and WUE. Overall, LT increased growth and production of brussels sprouts in all trials (Tables 4 and 5). By contrast, the color of plastic mulch had no effect on plant growth and yield, and there was no interaction between mulch color and LT for any parameter. Low tunnels increased leaf area by $57 \%$ and $67 \%$ at 60 DAT in Spring 2017 and 2018, respectively, and by 44\% at harvest in Fall 2017 (Table 4). Low tunnel also increased leaf dry weight by $31 \%$ and $21 \%$ at 60 DAT in Spring 2017 and 2018, respectively, and by $42 \%$ at harvest in Fall 2017 (data not presented). Specific leaf area was the same under LT and open field at harvest in Fall 2017. By contrast, specific leaf areas under LT at 60 DAT in Spring 2017 and 2018 were $27 \%$ and $37 \%$ greater than that in open field, respectively (Table 4). Plants under LT were also taller than those in open field in all trials. Plant height at harvest was $45 \%, 43 \%$, and $62 \%$ taller under LT than in open field in Spring 2017, Fall 2017, and Spring 2018, respectively (Table 4). In addition, overall growth under LT as determined by total plant dry weight increased by $26 \%$ and 37\% in both Spring 2017 and 2018, respectively, in comparison with those in open field (Table 5).

Low tunnels increased the number of sprouts per plant, which resulted in greater yield than in open field. Plants grown under LT produced 15.4 (29\%), 14.1 (22\%), and 12 $(29 \%)$ more sprouts in Spring 2017, Fall 2017, and Spring 2018, respectively (Table 5). The average sprout weight in Spring 2017 was $0.4 \mathrm{~g}$ greater under LT than in open field; however, sprout weight was the same in Fall 2017 and Spring 2018. Because of the increased number of sprouts per plant, yield increased by

Table 2. Soil temperatures $15 \mathrm{~cm}$ below soil surface in Brussels sprouts production under low tunnel (LT) and open field conditions.

\begin{tabular}{|c|c|c|c|c|c|c|c|c|}
\hline \multirow[b]{3}{*}{ Treatment } & \multirow{2}{*}{$\frac{\text { Spring } 2017}{\text { Maximum }}$} & \multicolumn{2}{|c|}{ Fall 2017} & \multicolumn{2}{|c|}{ Spring 2018} & \multicolumn{3}{|c|}{ Spring 2017} \\
\hline & & Maximum & Minimum & Maximum & Minimum & \multicolumn{3}{|c|}{ Minimum } \\
\hline & ---------------- & -------------' & -------------' & $\left({ }^{\circ} \mathrm{C}\right)$ & -------------' & -------- & ---------- & --------- \\
\hline \multicolumn{9}{|l|}{$\overline{\text { Mulch }}$} \\
\hline \multirow[t]{2}{*}{ White } & 22.2 & $22.6 \mathrm{~b}$ & 20.5 & $26.7 \mathrm{~b}$ & $23.9 \mathrm{~b}$ & & Open & $20.0 \mathrm{~b}$ \\
\hline & & & & & & White & LT & $19.9 \mathrm{~b}$ \\
\hline Tunnel & & & & & & & Open & $18.7 \mathrm{c}$ \\
\hline LT & 23.2 & 23.5 & $21.1 \mathrm{a}$ & 27.4 & $24.4 \mathrm{a}$ & & & \\
\hline Mulch & 0.054 & 0.026 & 0.162 & 0.016 & 0.017 & & & 0.023 \\
\hline Tunnel & 0.071 & 0.311 & $<0.0001$ & 0.177 & 0.027 & & & 0.005 \\
\hline $\mathrm{M} \times \mathrm{T}$ & 0.220 & 0.796 & 0.846 & 0.937 & 0.369 & & & 0.029 \\
\hline
\end{tabular}

${ }^{\mathrm{z}}$ Means within a column followed by different letters are significantly different from each other by Fischer's least significant difference at $P \leq 0.05$.

Open = open field; $\mathrm{M}=$ mulch; $\mathrm{T}=$ tunnel.

Table 3. Air temperature at canopy level ( $30 \mathrm{~cm}$ above soil surface) in brussels sprouts production under low tunnel (LT) and open field conditions.

\begin{tabular}{lccccc}
\hline & \multicolumn{2}{c}{ Spring 2017 } & \multicolumn{2}{c}{ Fall 2017 } & \multicolumn{2}{c}{ Spring 2018 } \\
\cline { 2 - 4 } & Maximum & Minimum & Maximum & Minimum & Maximum \\
\cline { 2 - 5 } Treatment & & 15.1 & 30.2 & 15.0 & $38.7 \mathrm{a}$ \\
\hline LT & $30.4 \mathrm{a}^{\mathrm{y}}$ & 15.5 & 24.6 & 14.3 & $30.1 \mathrm{~b}$ \\
Open field & $26.2 \mathrm{~b}$ & 0.669 & & & 0.022 \\
$P$ value & 0.009 & &
\end{tabular}

${ }^{\mathrm{z}}$ Fall 2017 trial had no replication for air temperature.

${ }^{\mathrm{y}}$ Means within a column followed by different letters are significantly different from each other by Fisher's least significant difference at $P \leq 0.05$. 


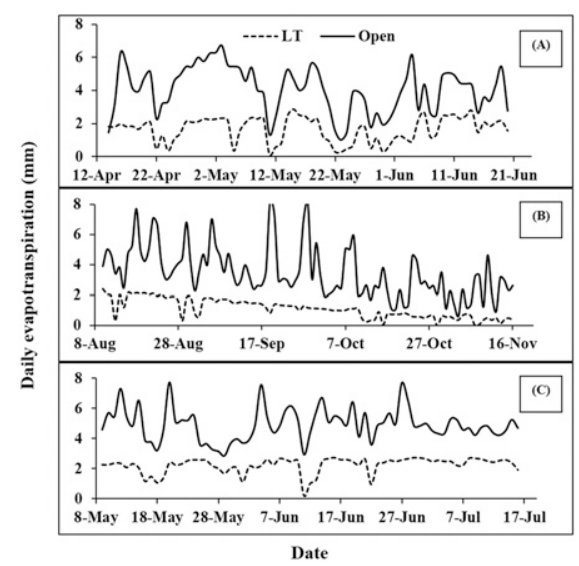

Fig. 1. Daily evapotranspiration at canopy levels in brussels sprouts grown under low tunnel (LT) and open field (Open). Air temperatures, solar radiation, relative humidity, and wind speed were used to determine evapotranspiration by using the Penman-Monteith equation (Synder and Eching, 2007). A = Spring 2017, B = Fall 2017, and C = Spring 2018 .

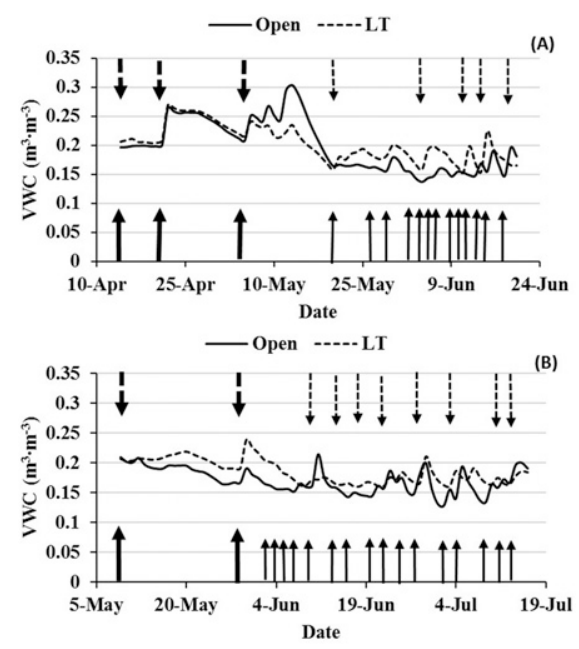

Fig. 2. Daily minimum volumetric water content (VWC), and timing of irrigation events in brussels sprouts grown under low tunnel (LT) and open field (Open). A = Spring 2017, B = Spring 2018. Data presented are from one replication in each trial. Arrows correspond to irrigation events. Darker arrow corresponds to irrigation events for plant establishment and fertilizer application applied to all subplots.

$1.28(46 \%), 3.44(46 \%)$, and $0.65 \mathrm{Mg} \cdot \mathrm{ha}^{-1}$ (22\%) under LT in Spring 2017, Fall 2017, and Spring 2018, respectively, in comparison with that in open field. However, when comparing the weight of the sprouts from the spring trials with that in the fall trial, spring sprouts were significantly lighter (49\%) than those in the fall trial.

Yield-, number of sprouts-, and dry weight-WUE increased under LT in both spring trials (Table 6). By contrast, there were no differences in WUE between black and white mulches, and no interaction between mulch color and LT except for sproutWUE in Spring 2017. Yield-WUE and dry
口LT @Open $\square$ LT $\Xi$ Open

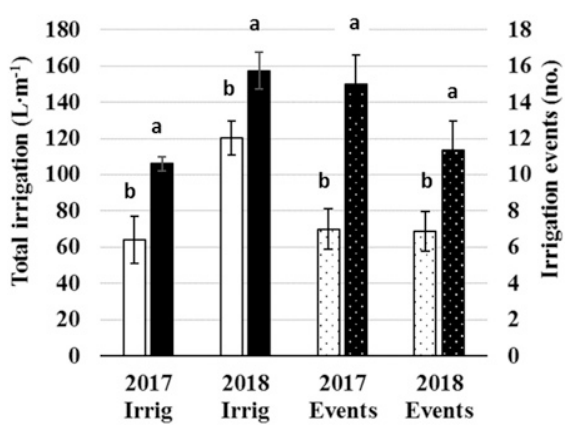

Fig. 3. Total applied irrigation water and number of irrigation events in brussels sprouts grown under low tunnel (LT) in comparison with open field (Open). Spring 2017 and 2018. Mean total applied irrigation water (Irrig) and mean irrigation events within a year followed by different letters are significantly different from each other by Fisher's least significant difference at $P \leq 0.05$. Bars in each column correspond to the SE.

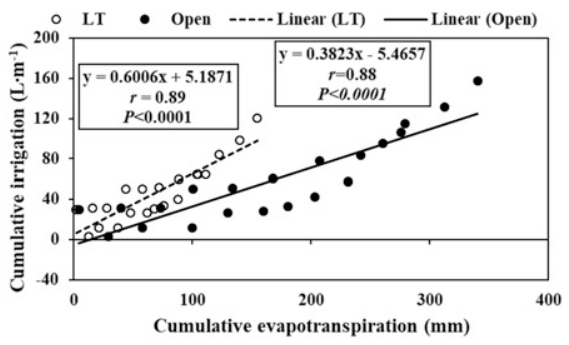

Fig. 4. Relationship between cumulative evapotranspiration and cumulative irrigation in brussels sprouts grown under low tunnel (LT) and open field (Open). Each point corresponds to weekly measurement from both Spring 2017 and Spring 2018 trials. $r$ is the correlation coefficient.

weight-WUE increased by $107 \%$ and $82 \%$, respectively, under LT in comparison with those in open field in Spring 2017 (Table 6). Similarly, in Spring 2018, yield-WUE, sprouts-WUE, and dry weight-WUE under LT were $62 \%, 70 \%$, and $81 \%$ greater than those in open field, respectively. SproutsWUE in Spring 2017 also increased under LT in both black $(97 \%)$ and white $(70 \%)$ mulches in comparison with open field, but sprouts-WUE was greater under LT and black mulch than under LT and white mulch.

\section{Discussion}

Environmental parameters and irrigation. Black mulch and LT slightly increased soil temperature with some exceptions, but plant size, shading, and soil depth were influencing factors. Black plastic mulch absorbs more solar energy in comparison with white plastic mulch, resulting in warmer soil, which is supported by the increase in maximum soil temperature in Fall 2017 and Spring 2018, and minimum soil temperature in both spring trials (Table 2) (Arancibia and Motsenbocker, 2008; Lamont, 2005; Soltani et al., 1995). The slight increase in soil temperature under black mulch was mainly early in the season when plants were small with little shading (data not presented). Late in the growing period, soil temperatures were the same likely because of less SR (fall), the shading effects of large mature plants, and the depth of the sensor.

Similarly, LT increased minimum soil temperature, but maximum soil temperature was the same in all trials (Table 2). Fewer differences in soil temperatures are likely because of increased plant shading and placement depth of soil temperature sensors. In this study, soil temperature sensors were 15 $\mathrm{cm}$ deep in the soil. Similar studies with muskmelon, tomato, and cucumber where sensors were $15 \mathrm{~cm}$ deep showed no differences in soil temperature between LT and open field (Tillman et al., 2015; Wolfe et al., 1989). By contrast, in studies that reported differences in soil temperatures, sensors were $5 \mathrm{~cm}$ deep (Arancibia and Motsenbocker, 2008; Nair and Ngouajio, 2010) and $10 \mathrm{~cm}$ deep (Ibarra et al., 2001; Ibarra-Jiménez et al., 2004; Soltani et al., 1995)

Rowcovers modified the microenvironment inside LTs, which reduced ET. The increase in maximum air temperatures under LT in comparison with open field (Table 3) agrees with previous reports (Arancibia and Motsenbocker, 2008; Ibarra et al., 2001; Nair and Ngouajio, 2010; Tillman et al., 2015). Furthermore, the reduction in SR under tunnels in this study is also in agreement with previous reports, and it is specified by the manufacturers of the rowcovers (Arancibia, 2009, 2012; Nair and Ngouajio, 2010; Tillman et al., 2015). It is worth noting that the thickness of the rowcover material influences light transmission. The small increase in the maximum $\mathrm{RH}$ in this study is inconsistent with previous reports where spunbonded rowcovers had little or no effect on RH (Arancibia, 2009, 2012). In addition, the maximum $\mathrm{RH}$ occurred mainly at night when ET is very low or zero. Therefore, in spite of the increased maximum air temperature, the reduced light intensity and lack of wind under the tunnel significantly reduced ET in comparison with open field (Fig. 1; Arancibia, 2009, 2012).

Less ET under LT reduced the crop's water needs and irrigation requirements in comparison with open field. The reduced ET under the LT decreased the rate of soil moisture loss, so it took longer for soil to dry to $50 \%$ plant available water content (Fig. 2). Because soil moisture dictated the time to irrigate, less irrigation events were necessary throughout the growing period to replenish soil moisture and the total amount of applied water was reduced (Fig. 3). However, the relationship between cumulative ET and cumulative irrigation were different between LT and open field (Fig. 4). This suggests that plant size and the rate of soil moisture loss, and/or other factor(s) are influencing these relationships. To our knowledge, this is the first report that demonstrates that LTs reduce irrigation needs in comparison with open field. 
Table 4. Leaf area, specific leaf area, and plant height in brussels sprouts grown under low tunnel (LT) and open field conditions.

\begin{tabular}{|c|c|c|c|c|c|c|c|c|c|}
\hline \multirow[b]{3}{*}{ Treatment } & \multicolumn{3}{|c|}{ Leaf area $\left(\mathrm{cm}^{2}\right)$} & \multicolumn{3}{|c|}{ Specific leaf area $\left(\mathrm{cm} \cdot \mathrm{g}^{-1}\right)$} & \multicolumn{3}{|c|}{ Plant ht $(\mathrm{cm})$} \\
\hline & Spring 2017 & Fall 2017 & Spring 2018 & Spring 2017 & Fall 2018 & Spring 2018 & Spring 2017 & Fall 2017 & Spring 2018 \\
\hline & $\overline{60 \mathrm{DAT}}$ & Harvest & $60 \mathrm{DAT}$ & $60 \mathrm{DAT}$ & Harvest & $60 \mathrm{DAT}$ & Harvest & Harvest & Harvest \\
\hline LT & $26,152 a^{z}$ & $26,648 \mathrm{a}$ & $14,813 \mathrm{a}$ & $100 \mathrm{a}$ & 107 & $104 \mathrm{a}$ & $67.7 \mathrm{a}$ & $66.7 \mathrm{a}$ & $50.3 \mathrm{a}$ \\
\hline $\begin{array}{l}\text { Open field } \\
P \text { value }\end{array}$ & $16,602 \mathrm{~b}$ & $18,486 \mathrm{~b}$ & $8,895 \mathrm{~b}$ & $80 \mathrm{~b}$ & 106 & $76 \mathrm{~b}$ & $46.7 \mathrm{~b}$ & $46.6 \mathrm{~b}$ & $31.0 \mathrm{~b}$ \\
\hline Mulch & 0.541 & 0.719 & 0.679 & 0.438 & 0.785 & 0.960 & 0.796 & 0.342 & 0.276 \\
\hline LT & $<0.0001$ & $<0.0001$ & 0.002 & 0.047 & 0.962 & $<0.0001$ & $<0.0001$ & $<0.0001$ & $<0.0001$ \\
\hline $\mathrm{M} \times \mathrm{LT}$ & 0.105 & 0.788 & 0.348 & 0.063 & 0.225 & 0.563 & 0.181 & 0.237 & 0.857 \\
\hline
\end{tabular}

${ }^{\mathrm{z}}$ Means within a column followed by different letters are significantly different from each other by Fisher's least significant difference at $P \leq 0.05$.

$\mathrm{DAT}=$ days after transplanting; $\mathrm{M}=$ mulch.

Table 5. Yield, number of sprouts per plant, sprout weight, and plant dry weight in brussels sprouts grown under low tunnel (LT) and open field conditions.

\begin{tabular}{|c|c|c|c|c|c|c|c|c|c|c|c|}
\hline \multirow[b]{2}{*}{ Treatment } & \multicolumn{3}{|c|}{ Yield $\left(\mathrm{Mg} \cdot \mathrm{ha}^{-1}\right)$} & \multicolumn{3}{|c|}{ Sprouts per plant (no.) } & \multicolumn{3}{|c|}{ Sprout wt (g) } & \multicolumn{2}{|c|}{ Plant dry wt (g) } \\
\hline & Spring 2017 & Fall 2017 & Spring 2018 & Spring 2017 & Fall 2017 & Spring 2018 & Spring 2017 & Fall 2017 & Spring 2018 & Spring 2017 & Spring 2018 \\
\hline$\overline{\mathrm{LT}}$ & $4.1 \mathrm{a}^{\mathrm{z}}$ & $10.8 \mathrm{a}$ & $3.3 \mathrm{a}$ & $68.8 \mathrm{a}$ & $77.3 \mathrm{a}$ & $53.8 \mathrm{a}$ & $3.3 \mathrm{a}$ & 7.7 & 4.2 & $269 \mathrm{a}$ & $292 \mathrm{a}$ \\
\hline $\begin{array}{l}\text { Open field } \\
P \text { value }\end{array}$ & $2.8 \mathrm{~b}$ & $7.4 \mathrm{~b}$ & $2.7 \mathrm{~b}$ & $53.4 \mathrm{~b}$ & $63.2 \mathrm{~b}$ & $41.8 \mathrm{~b}$ & $2.9 \mathrm{~b}$ & 6.7 & 4.3 & $213 \mathrm{~b}$ & $213 \mathrm{~b}$ \\
\hline Mulch & 0.072 & 0.975 & 0.992 & 0.441 & 0.445 & 0.606 & 0.148 & 0.689 & 0.94 & 0.837 & 0.089 \\
\hline $\mathrm{LT}$ & 0.001 & 0.047 & 0.045 & $<0.0001$ & 0.005 & $<0.0001$ & 0.02 & 0.335 & 0.883 & 0.049 & 0.005 \\
\hline $\mathrm{M} \times \mathrm{LT}$ & 0.331 & 0.912 & 0.892 & 0.353 & 0.182 & 0.634 & 0.533 & 0.074 & 0.909 & 0.524 & 0.178 \\
\hline
\end{tabular}

${ }^{\mathrm{z}}$ Means within a column followed by different letters are significantly different from each other by Fisher's least significant difference at $P \leq 0.05$. $\mathrm{M}=$ mulch.

Table 6. Water-use efficiency (WUE) with respect to yield, plant dry weight, and sprouts in brussels sprouts production under low tunnel (LT) and open field conditions.

\begin{tabular}{|c|c|c|c|c|c|c|c|}
\hline \multirow[b]{3}{*}{ Treatment } & \multirow{2}{*}{\multicolumn{2}{|c|}{ Yield WUE $\left(\mathrm{g} \cdot \mathrm{L}^{-1}\right)$}} & \multirow{2}{*}{\multicolumn{2}{|c|}{ Dry wt WUE $\left(\mathrm{g} \cdot \mathrm{L}^{-1}\right)$}} & \multicolumn{3}{|c|}{ Sprouts WUE (no./L) } \\
\hline & & & & & \multirow[b]{2}{*}{ Spring 2018} & \multicolumn{2}{|c|}{ Spring 2017} \\
\hline & Spring 2017 & Spring 2018 & Spring 2017 & Spring 2018 & & Black & White \\
\hline$\overline{\mathrm{LT}}$ & $7.41 \mathrm{a}^{\mathrm{z}}$ & $5.19 \mathrm{a}$ & $8.87 \mathrm{a}$ & $8.33 \mathrm{a}$ & $1.55 \mathrm{a}$ & $2.54 \mathrm{a}$ & $2.04 \mathrm{~b}$ \\
\hline Open field & $3.57 \mathrm{~b}$ & $3.21 \mathrm{~b}$ & $4.87 \mathrm{~b}$ & $4.61 \mathrm{~b}$ & $0.91 \mathrm{~b}$ & $1.29 \mathrm{c}$ & $1.20 \mathrm{c}$ \\
\hline \multicolumn{8}{|l|}{$P$ value } \\
\hline Mulch & 0.128 & 0.533 & 0.224 & 0.282 & 0.553 & \multicolumn{2}{|c|}{$<0.0001$} \\
\hline LT & $<0.0001$ & 0.003 & 0.002 & 0.007 & 0.003 & \multicolumn{2}{|c|}{$<0.0001$} \\
\hline $\mathrm{M} \times \mathrm{LT}$ & 0.266 & 0.725 & 0.073 & 0.566 & 0.725 & \multicolumn{2}{|c|}{0.005} \\
\hline
\end{tabular}

${ }^{\mathrm{z}}$ Means within a column followed by different letters are significantly different from each other by Fisher's least significant difference at $P \leq 0.05$.

$\mathrm{M}=$ mulch.

Growth, production, and WUE. Low tunnel enhanced vegetative growth and yield, and improved WUE. In this study, LT increased vegetative growth of brussels sprouts as measured by plant leaf area, leaf dry weight, plant dry weight, and plant height in all trials in comparison with open field (Tables 4 and 5). These results agree with previous reports indicating that rowcovers enhance vegetative growth and production of vegetable crops (Arancibia and Motsenbocker, 2008; Ibarra et al., 2001; Ibarra-Jiménez et al., 2004; Jolliffe and Gaye, 1995; Nair and Ngouajio, 2010; Soltani et al., 1995; Tillman et al., 2015). However, differences in specific leaf area between LT and open field were inconsistent among trials likely because of the time of sampling. Differences were not evident at harvest in Fall 2017, but specific leaf area increased at 60 DAT in both Spring 2017 and 2018. Soltani et al. (1995) also found inconsistencies in specific leaf area in samples taken overtime during plant growth and over the years, but concluded that, in general, rowcover increases specific leaf area. Therefore, the microenvironmental conditions under LT increase leaf area mainly by increasing leaf dry weight, and the increase in specific leaf area (reduced density) plays a secondary role.

Favorable microenvironmental conditions under LT enhanced vegetative growth and increased yield in brussels sprouts. Most reports have attributed the larger plants and yield of vegetable crops grown under rowcovers to increased temperatures and accumulated growing degree-days (Arancibia and Motsenbocker, 2008; Ibarra et al., 2001; Nair and Ngouajio, 2010; Soltani et al., 1995; Tillman et al., 2015). However, based on the results of this study, reduced ET and water stress appear to have contributed to the increase in vegetative growth and yield in addition to temperatures (Fig. 1; Tables 3-5).

Greater yield under LT was predominantly due to more sprouts per plant than sprout size. Most sprouts were wider than $2.5 \mathrm{~cm}$ in diameter at harvest and differences in weight between LT and open field were inconsistent, suggesting that LT has no effect on sprouts size. However, there was a difference in sprout weight between the fall trial (heavier and denser) compared with the spring trials. Heavier sprouts in the fall were because of cooler temperatures during sprout development in contrast to warmer temperatures in the spring trials. Optimal temperature for sprouts development ranges between 5 and $18{ }^{\circ} \mathrm{C}$ (Welbaum, 2015). Therefore, brussels sprouts for spring production should be planted much earlier in spring to improve quality.

Increased yield and reduced irrigation contributed to improved WUE under LT. The modification of the microenvironment under LT (reduced SR and no wind) reduced ET and crop irrigation needs while increasing growth and productivity (Fig. 2; Table 5). Therefore, the ratio of increased growth and reduced applied water demonstrated that LT increase WUE (Table 6). This is the first report to our knowledge presenting evidence that LTs reduced irrigation needs and increased WUE.

\section{Conclusions}

This study showed additional benefits of using LTs in vegetable crops with the potential to increase sustainability. Low tunnels modified the microenvironment by increasing soil and air temperatures and reducing ET in comparison with open field, which resulted in increased vegetative growth and yield of brussels sprouts. In addition, less ET under LT reduced the rate of soil moisture loss and irrigation needs, and likely reduced water 
stress on sunny and/or windy days. Therefore, the combined effect of reduced irrigation and increased yield improved the WUE of brussels sprouts grown under LTs.

\section{Literature Cited}

Abdrabbo, M., A. Farag, M. Hassanein, and A. Abou-Hadid. 2010. Water consumption of eggplant under different microclimates. J. Biol. Chem. Environ. Sci. 5:239-255.

Allen, R.G., L.S. Pereira, D. Raes, and M. Smith 1998. Crop evapotranspiration-guidelines for computing crop water requirements-FAO irrigation and drainage paper 56. FAO, Rome. 8 Nov. 2017. <http://www.fao.org/docrep/X0490E/ X0490E00.htm>.

Arancibia, R.A. 2009. Microclimatic factors associated with enhanced plant growth under rowcover. HortScience 44:1132 (abstr.).

Arancibia, R.A. 2012. Rowcovers in vegetable crops production in tropical and temperate climates. HortScience 47:S107-S108 (abstr.).

Arancibia, R.A. 2018. Low tunnels in vegetable crops: Beyond season extension. Virginia Coop. Ext., Virginia Tech. VCE Pub. HORT291. 29 June 2018. <https://pubs.ext.vt.edu/ HORT/HORT-291/HORT-291.html>.

Arancibia, R.A. and C.E. Motsenbocker. 2008 Differential watermelon fruit size distribution in response to plastic mulch and spunbonded polyester rowcover. HortTechnology 18:45-52.

Feigin, A., J. Letey, and W. Jarrell. 1982. Nitrogen utilization efficiency by drip irrigated celery receiving preplant or water applied $\mathrm{N}$ fertilizer. Agron. J. 74:978-983.

Gallardo, M., L. Jackson, K. Schulbach, R. Snyder, R. Thompson, and L. Wyland. 1996. Production and water use in lettuces under variable water supply. Irr. Sci. 16:125-137.

Gerber, J.M., I. Mohd-Khir, and W.E. Splittstoesser. 1988. Row tunnel effects on growth, yield and fruit quality of bell pepper. Scientia Hort. 36:191-197.

Ibarra, L., J. Flores, and J.C. Dì̀az-Pérez. 2001 Growth and yield of muskmelon in response to plastic mulch and row covers. Scientia Hort. 87:139-145.

Ibarra-Jiménez, L., M. Quezada-Martín, and M. de la Rosa-Ibarra. 2004. The effect of plastic mulch and rowcovers on the growth and physiology of cucumber. Austral. J. Expt. Agr. 44:91-94.

Jensen, M.E. and R.G. Allen. 2016. Evaporation, evapotranspiration, and irrigation water requirements. ASCE, Reston, VA.

Jolliffe, P.A. and M-M. Gaye. 1995. Dynamics of growth and yield component responses of bell peppers (Capsicum annuum L.) to row covers and population density. Scientia Hort. 62:153-164.

Lamont, W.J. 2005. Plastics: Modifying the microclimate for the production of vegetable crops. HortTechnology 15:477-481.

Morison, J., N. Baker, P. Mullineaux, and W. Davies. 2008. Improving water use in crop production. Philos. Trans. R. Soc. Lond. B Biol. Sci. 363:639-658.

Nair, A. and M. Ngouajio. 2010. Integrating rowcovers and soil amendments for organic cucumber production: Implications on crop growth, yield, and microclimate. HortScience 45:566-574.

Sammis, T.W. 1980. Comparison of sprinkler, trickle, subsurface, and furrow irrigation methods for row crops. Agron. J. 72:701-704.

Soltani, N., J.L. Anderson, and A.R. Hamson 1995. Growth analysis of watermelon plants grown with mulches and rowcovers. J. Amer. Soc. Hort. Sci. 120:1001-1009.

Synder, R.L. and S. Eching. 2007. PMday. PenmanMontein daily. Univ. California, Davis. 8 Aug. 2017. <http://biomet.ucdavis.edu/index.php? option $=$ com_content\&view $=$ article \&id $=19 \&$ Itemid $=32>$.

Tillman, J., A. Nair, M. Gleason, and J. Batzer. 2015. Evaluating strip tillage and rowcover use in organic and conventional muskmelon production. HortTechnology 25:487-495.

U.S. Department of Agriculture. 2013. Microirrigation. Part 623 irrigation national engineering handbook. U.S. Dept. Agr. Natural Resources Conservation Serv. 2 Feb. 2017. <https://www. nrcs.usda.gov/wps/portal/nrcs/detailfull/national/ water/manage/irrigation/?cid=stelprdb1045075 >

U.S. Department of Agriculture. 2016. United States standards for grades of Brussels sprouts. U.S. Dept. Agr. Agricultural Marketing Serv. 3 Feb. 2017. <https://www.ams.usda. gov/grades-standards/brussels-sprouts-grades-andstandards $>$.

U.S. Department of Agriculture. 2017. Vegetable and pulses data. U.S. Dept. Agr. Economic Res. Serv. 6 June 2018. <https://www.ers.usda.gov/ data-products/vegetables-and-pulses-data/ $>$.

U.S. Department of Agriculture. 2018. Seasonal produce guide-what's in season? 29 June 2018. $<$ https://snaped.fns.usda.gov/seasonal-produceguide $>$.

Welbaum, G.E. 2015. Vegetables production practices: Family Brassicaceae. CABI, Wallingford, UK

Wolfe, D., L. Albright, and J. Wyland. 1989 Modeling rowcover effects on microclimate and yield. I. Growth response of tomato and cucumber. J. Amer. Soc. Hort. Sci. 114:562568.

Wyenandt, C.A. 2016. Mid-Atlantic commercial vegetables production recommendation. Virginia Coop. Ext. Virginia Tech. Virginia State Univ. 25 Dec. 2016. VCE Pub. 456-420. $<$ http://pubs.ext.vt.edu/456/456-420/456-420. html>

Zotarelli, L., M.D. Dukes, C.C. Romero, K.W Migliaccio, and K.T. Morgan. 2010. Step by step calculation of the Penman-Monteith evapotranspiration (FAO-56 method). Inst Food Agr. Sci. Univ. Florida. Pub. \#AE459. 15 Jan. 2017. <http://edis.ifas.ufl.edu/ae459>. 